\title{
Study of Production and Characterization of Laccase Enzyme from Klebsiellapneumoniae K7 Isolate
}

\author{
Doaa Khalid Mezaal $^{1}$, Essam Fadel Al-Jumaili ${ }^{1}$, Ahmed Majeed Al-Shammari ${ }^{2}$ \\ ${ }^{I}$ Doctorol Degree Student, Prof., Biotechnology Dept. Genetic Engineering and Biotechnology Institute for Post \\ Graduate Studies/University of Baghdad/Iraq, 2Assiant Prof., Experimental Therapy Dept. Iraqi Centre for Cancer \\ Medical Genetic Research, Mastansiriyeh University
}

\begin{abstract}
Sixty four local isolated of Klebsiella spp. have been isolated from environment samples (soil and water). These isolates were identified and diagnosis according to phenotype and biochemical tests. These isolates were subjected to primary and secondary screening, to select the isolate with the highest laccase activity. Fifteen isolates chosen from primary screening for screening their enzyme activity in secondary screening. It has been found the Klebsiella $(\mathrm{K} 7)$ has the highest productivity of the enzyme (12 Unit/ml).Klebsiella $(\mathrm{K} 7)$ isolate was diagnosis by Vitak 2 system, it was identified asK. pneumonia. The laccase purified was characterization, the experiments showed that: The molecular weight of laccase was $120 \mathrm{KD}$ and the optimum $\mathrm{pH}$ for the purified laccase activity was 4.5 and forstability was 6.5 . the optimum temperature for enzyme activity was $40^{\circ} \mathrm{C}$, the enzyme showed that laccase lost 22,23 and $20 \%$ of its initial activity at 20,25 and $35^{\circ} \mathrm{C}$, respectively.
\end{abstract}

Keywords: Klebsiella (K7, laccase enzyme, Enzyme characterization, Enzyme kinetic.

\section{Introduction}

Laccase (EC 1.10.3.2) is one of the important of multicopper oxidasesenzymes, these enzymes have the ability to oxidize a wide range of organic, and inorganic compounds, including diphenols, polyphenols, substituted phenols, diamines and aromatic amines, this reaction would reduction of molecular oxygen to water ${ }^{[1]}$. Bacteria are become a featured source of laccase production, the used of bacterial laccase in different applications are growing rapidly, this is due to many reasons such as bacteria are easy to handle, the word in different environmental conditions and the bacterial laccase activity and stability at high temperatureand

\section{Correspondence Author:}

\section{Dr. Essam Fadel Al-Jumaili}

Professor, Biotechnology Dept. Genetic Engineering and Biotechnology Institute for Post Graduate Studies/ University of Baghdad/Iraq e-mail: professordraljumily@gmail.com natural $\mathrm{pH}^{[2]}$. Klebsiella spp. is one of the interesting laccase source ${ }^{[3]}$. The Klebsiellais a genus of Gramnegative, non-motile,facultative anaerobic, rod-shaped (ranging from 0.3 to $1.0 \mu \mathrm{m}$ in width to $0.6-6.0 \mu \mathrm{m}$ in length), generally with polysaccharide-based capsule bacteria. Unlike other enzymes of oxidoreductases and peroxidase $^{[4]}$, The bacterial laccases were found to be thermostable and alkaline stable by Sharma et al. ${ }^{[5]}$. Laccase activity vary by changing $\mathrm{pH}$, this variation may be due tothe reaction caused by the binding of enzyme to substrate,ionization of the substrate, oxygen, or the enzyme itself $f^{[6]}$. The most thermos table laccases have been isolated frombacteria; the halflife of Bacillus subtilis CotA was $112 \mathrm{~min}$ at $80^{\circ} \mathrm{C}^{[7]}$ and that of Streptomyces lavendulae laccase was 100 $\min$ at $70^{\circ} \mathrm{C}^{[8]}$. These properties of laccase make it has many applications in industrial, environmental (paper, pulp, textiles and bioremediation) and in medical fields (synthesis complex medical products such as antibiotics and anticancer drugs) ${ }^{[9]}$. The aim of this study is an attempt to screening of laccase producing Klebsiella, and select the isolate with the highest enzyme activity and characterization of laccase enzyme. 


\section{Materials and Method}

ABTS plate screen assay: The isolates showing methyl orange degradation were further screened for enzyme laccase, on this media which prepared by adding $0.2 \mathrm{mM} \mathrm{ABTS}$ and $0.1 \mathrm{mM} \mathrm{CuSO}_{4}$ (after filtering them) in Mineral Salt Agar. Blue green oxidation zone around the bacteria colony indicated the presence of laccase.

Laccase assay: Laccase activity was monitored by measuring the maximum absorption of oxidation of $\mathrm{ABTS}$ at $25^{\circ} \mathrm{C}$ as a substrate. The reaction mixture containing $1 \mathrm{ml}$ of crude enzyme and $1 \mathrm{ml}$ of ABTS $(0.2 \mathrm{mM})$. The oxidation of ABTS was determined by measuring the absorbance at $420 \mathrm{~nm}$. The blank mixture containing $1 \mathrm{ml}$ of sodium acetate buffer $(0.1 \mathrm{mM}$, pH5) and $1 \mathrm{ml}$ of ABTS . Laccase activity was calculated as follows:

$$
\text { Laccase activity }\left(\frac{\mathrm{U}}{\mathrm{ml}}\right)=\frac{\mathrm{A} \times \mathrm{V} \times 106}{€ \mathrm{ABTS} \times \mathrm{t} \times \mathrm{V}}
$$

Where: A: Absorbance at 420nm; V: Total volume of reaction mixture in $(\mathrm{ml})$; $€$ : molar extinction coefficient of ABTS $=36000 \mathrm{M}^{-1} \mathrm{~cm}^{-1}$; t:incubation time $(1 \mathrm{~min})$ and $\mathrm{v}$ : volume of enzyme used in $(\mathrm{ml})^{[10]}$. Protein concentration was assayed by the method of Bradford ${ }^{[11]}$.

Effect of pH on Enzyme Activity: The effect of $\mathrm{pH}$ on the activity of the laccase was determined at $37^{\circ} \mathrm{C}$ in $0.05 \mathrm{M}$ Tric- $\mathrm{HCl}$ buffer $(\mathrm{pH} 3,3.5,4,4.5,5,5.5$, 6) $0.05 \mathrm{M}$ sodium phosphate buffer ( $\mathrm{pH} 6.5,7,7.5,8)$ and $0.05 \mathrm{M}$ Tris-base buffer $(\mathrm{pH} 8)$. The laccase activity was determined at different $\mathrm{pH}$ (4-9) by mixing $1 \mathrm{ml}$ of ABTS with $1 \mathrm{ml}$ of purified enzyme and the activity was measured with different buffers.

Effect of pH on Enzyme Stability: The effect of $\mathrm{pH}$ on laccase stability was examined by adding $1 \mathrm{ml}$ of enzyme of to a test tubes containing buffer at different $\mathrm{pH}(3,3.5,4,4.5,5,5.5,6,6.5,7,7.5,8)$, and incubated $30 \mathrm{~min}$ at $37^{\circ} \mathrm{C}$ in a water bath, then added the ABTS to mixer and measured the activity with different buffers.

Effect of Temperature on Enzyme Activity: The temperature profile of the purified enzyme was studied by measuring the activity at different temperatures $(25,30$, $35,40,45,50,55,60)^{\circ} \mathrm{C}$. The purified laccase solution was incubated with ABTS in different temperatures for 10 min and the activity was determined.

Effect of Temperature on Enzyme Stability: The purified laccase was incubated at different temperature ranged between $(25,30,35,40,45,50,55,60,65,70)^{\circ} \mathrm{C}$. followed by incubation in ice bathfor $30 \mathrm{~min}$. The enzyme activity was assayed using ABTS, and the relation between remaining activity (\%) toward temperature was plotted to determine the optimum temperature of laccase stability.

Laccase Kinetics : $K_{m}, V_{\text {max }}$ values determination: Pre-steady state kinetic analysis was performed using ABTS at different concentration $(0.1,0.15,0.2$, $0.25,0.3 \mathrm{mM}$ ) in $0.1 \mathrm{mM}$ of sodium acetate buffer at $\mathrm{pH} 5$ and estimate the enzyme activity, then the initial velocity $\left(\mathrm{V}_{\mathrm{o}}\right)$ value was estimated. The relationship between [1/ $\mathrm{V}_{\mathrm{o}}$ ] versus $\left[1 / \mathrm{S}_{\mathrm{o}}\right]$ was plotted to determine the $\mathrm{K}_{\mathrm{m}}$ and $\mathrm{V}_{\max }$ values according to Lineweaver-Burk reciprocal plot.

\section{Results and Discussion}

Screening of Klebsiella pneumoniae Isolates for Laccase Production: Out of sixty four Klebsiella pneumoniae isolates, there were thirty isolates showed a clear zone around the colony on methyl orange plate, these isolate further screened for enzyme laccase on ABTs plate, it found that twenty one give a positive results . The activity of the enzyme of the fifteen isolates of $K$. pneumoniae, that have ability to produce laccase, was measured to select the highest isolation activity for choose the isolate that have the highest activity (Table $1)$. The laccase activity was monitored by measuring the maximum absorption of oxidation of ABTS as a substrate.

Table (1) : Screening the Klebsiella pneumoniae producing Laccase enzyme.

\begin{tabular}{|c|c|}
\hline Klebsiella pneumoniae Isolates & Enzyme activity (Unit/ml) \\
\hline K1 & 8.23 \\
\hline K2 & 7.60 \\
\hline K3 & 10.23 \\
\hline K4 & 10.06 \\
\hline K5 & 9.37 \\
\hline K6 & 6.57 \\
\hline K7 & 12 \\
\hline K8 & 6.78 \\
\hline K9 & 7.83 \\
\hline K10 & 9.54 \\
\hline K11 & 6.97 \\
\hline K12 & 7.94 \\
\hline K15 & 7.21 \\
\hline
\end{tabular}


Molecular Weight Determination: The moleculare weight of purifed laccase was determinaed by Gel filtration chromatograph, which depending on the size of the separated molecules with their charge ${ }^{[12]}$, using Sephacryl S-200. The results in Figure (2) shows the relationship between logarithm of molecular weight and $(\mathrm{Ve} / \mathrm{Vo})$ of four different standard proteins in gel filtration column include Catalase (232KD), Arginine Deaminase (125.892KD), Bovine Serum albumin (67KD) and Pepsin (34.5KD), these proteins and laccase were eluted individually. The results in indicated that laccase has a molecular weight of (120KD). The molecular weight of laccase was determined which that purified from c-Proteobacterium JBBy using ABTS as substrate ${ }^{[13]}$. Also, Siroosiet al. ${ }^{[14]}$ estimated molecular weight of laccase from Bacillus sp. WT to be $180 \mathrm{KD}$ and Verma and Shirkot ${ }^{[15]}$ purified laccase from GeobacillusthermocatenulatusMS5 with molecular weight 42.5KD.By using another different substrates of laccase the molecular weight was estimated.

Effect of pH on Enzyme Activity: The optimum $\mathrm{pH}$ for laccase activity was determined with ABTS as substrate in a $\mathrm{pH}$ range of (3-7). As results in Figure (1), it was found that the best $\mathrm{pH}$ of laccase activity in ranged between $(4,4.5$ and 5$)$, with a maximum and sharp decline in enzyme activityat $\mathrm{pH} 4.5$ with enzyme activity $(2.8 \mathrm{U} / \mathrm{ml})$. While, observed that enzyme activy was reduced at nearly acidic $\mathrm{pH}(3,3.5)$ and at alkaline $\mathrm{pH}$ (5.5-7).

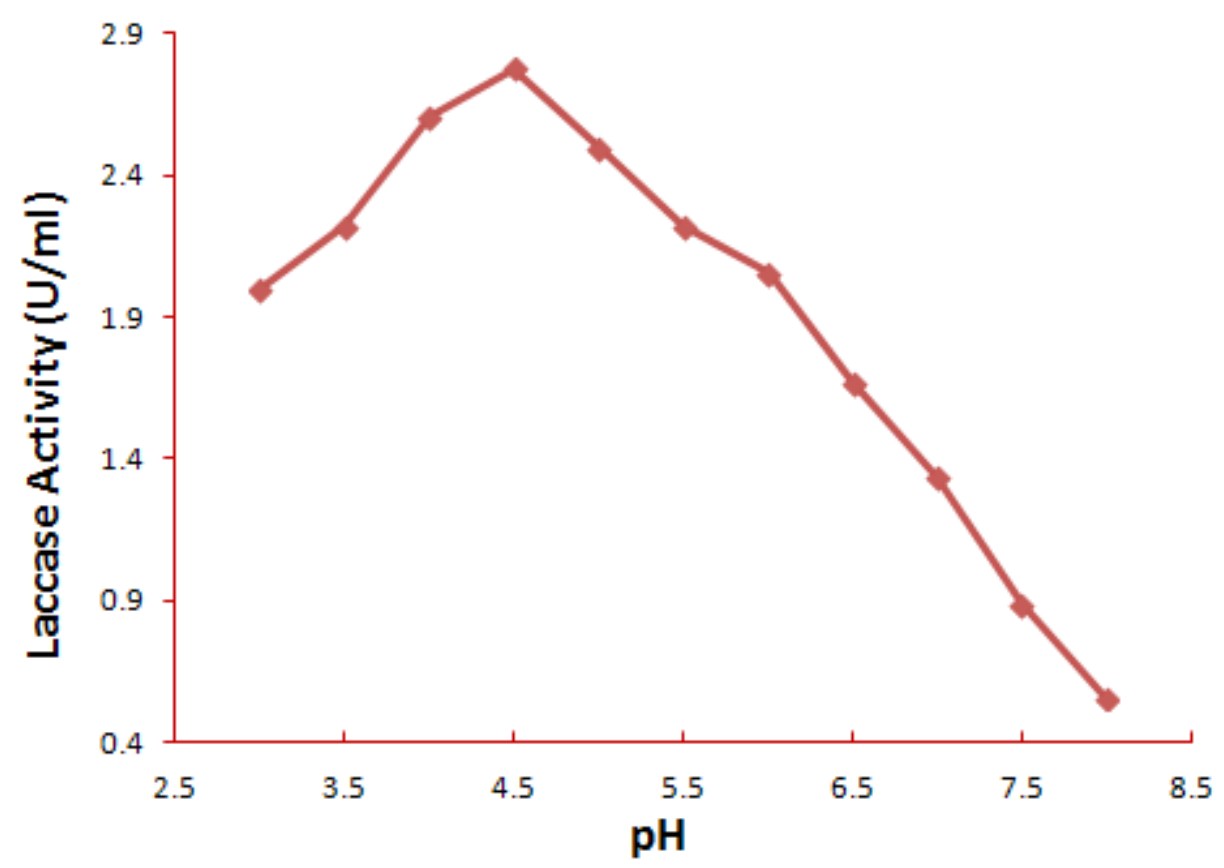

Figure (1): Effect of different pHon Laccase activity.

Verma and Shirkot ${ }^{[15]}$, and Liu et al. ${ }^{[16]}$ were purified laccase from Pseudomonas aeruginosa, Ochrobactrum. sp.531 and Thermu- thermophilus SG0.5JP17-16, receptivity by using ABTS as a substrate, found that the optimum $\mathrm{pH}$ of laccase activity was at 4.5. The optimum $\mathrm{pH}$ on laccase activity was at 4.5 , which purified fromTrametes versicolor .[17]

Compared to phenolic substrates, the redox potential of ABTS does not depend on the $\mathrm{pH}$, oxidation does not involve the protons. So, the effect of $\mathrm{pH}$ on the laccase activity towards the different substrates could be related to the balance between the two opposing effects, first the redox potential difference between the substrates and type 1 copper site and second binding of hydroxide anion $\left(\mathrm{OH}^{-}\right)$to the type $2 /$ type 3 copper site ${ }^{[18]}$.

Effect of pH on Enzyme Stability: Figure (2) shown that the optimum $\mathrm{pH}$ of laccase stability ranged between 6-7 and the a maximum stability was at $\mathrm{pH} 6.5$, where the enzyme retained $100 \%$ of its activity. While, retained $94.42 \%$ of its activity at $\mathrm{pH} 6$ and about $94.42 \%$ and $82.03 \%$ at $\mathrm{pH} 7$. 


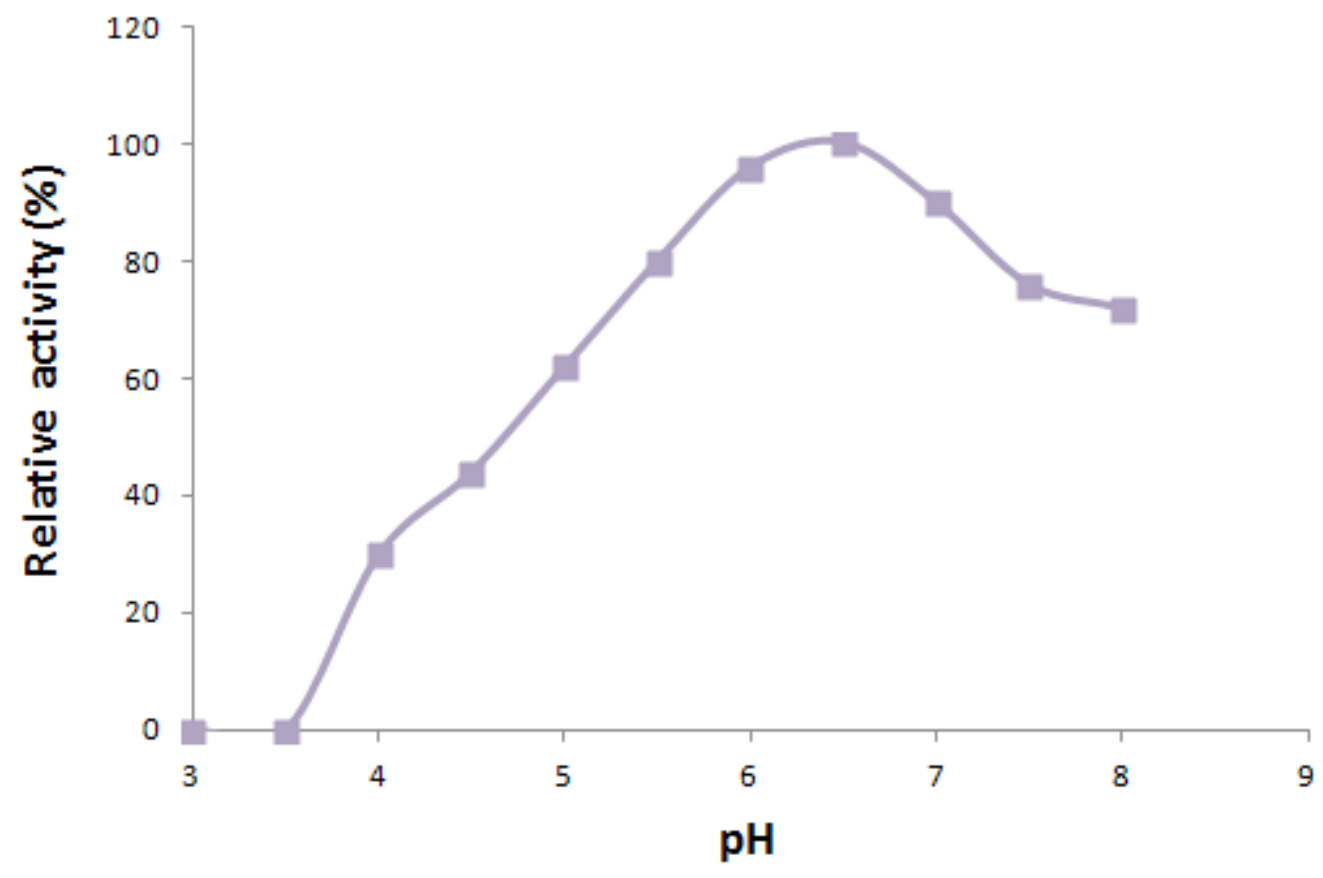

Figure (2): Effect of different pHon Laccase stability

The reason for decreasing in enzyme stability at acidic $\mathrm{pH}$ is due to the effect of acidic environment in enzymatic structure which cause ionizing groups in active site. The declining in enzyme activity at $\mathrm{pH}$ above the optimum $\mathrm{pH}$ may be due to irreversible denaturation of enzyme molecule that leads to change in enzyme structure associated with the formation of enzyme dimerization that leads to enzyme autolysis ${ }^{[19]}$.
Effect of Temperature on Enzyme Activity: The temperature profile of the laccase was studied by measuring the activity in a range of $25-60^{\circ} \mathrm{C}$ with $5^{\circ} \mathrm{C}$ interval. The results in Figure (3) showed an increase in laccase activity towards $40^{\circ} \mathrm{C}$ with an activity of $3.17 \mathrm{U} /$ $\mathrm{ml}$. After $40^{\circ} \mathrm{C}$ the activity decrease and the minimum activity was recorded at $60^{\circ} \mathrm{C}$ which was $2.5 \mathrm{U} / \mathrm{ml}$.

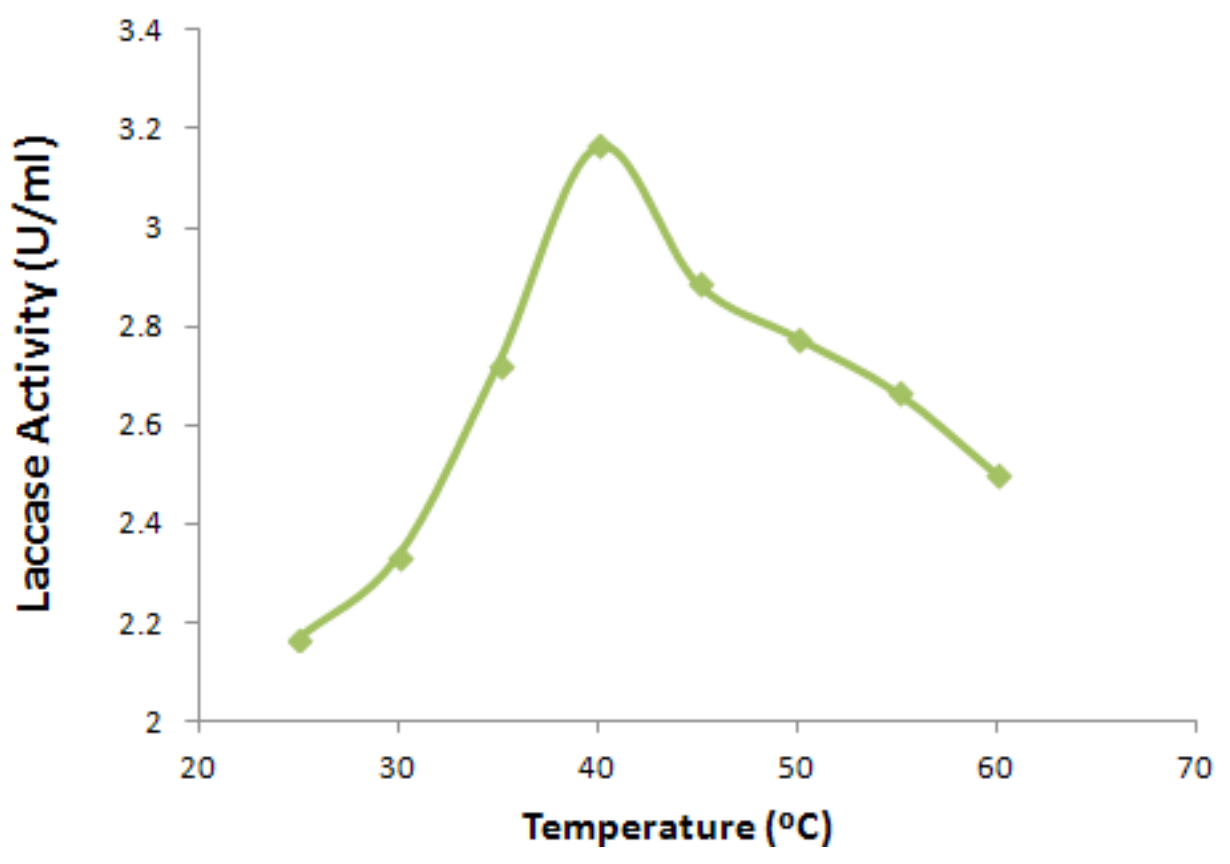

Figure (3): Effect of different temperatures on Laccase activity. 
Siroosiet al. ${ }^{[20]}$ determined the optimal temperature of laccase activity at $37^{\circ} \mathrm{C}$, which purified from Bacillus sp. WT, Pseudomonas aeruginosa and Rhodococcus sp., respectively. Demissie and Kumar ${ }^{[21]}$ found the optimal temperature, that purified from Streptomycetes $s p$. was at $35^{\circ} \mathrm{C}$. While, temperature was $35^{\circ} \mathrm{C}$ of laccase from Pseudomonas luridastrain LR5.1 determined by Dhiman and Shirkot ${ }^{[22]}$. The reason for decreasing of an enzyme activity towards higher temperature is that the speed of enzyme interaction increase with increasing temperature within a certain range due to increased energy kinetics and the collisions between enzyme molecules and substrate, except that the high temperatures within certain limits lead to denaturation of the enzyme and loss of three dimensional structure and then decline in enzyme activity. ${ }^{[23]}$

\section{Effect of Temperature on Enzyme Stability:} The thermostability of laccase was determined at temperatures ranging from 25 to $60^{\circ} \mathrm{C}$. The results in Figure (4) showed that laccase lost 22, 23 and $20 \%$ of its initial activity at 20,25 and $35^{\circ} \mathrm{C}$, respectively.

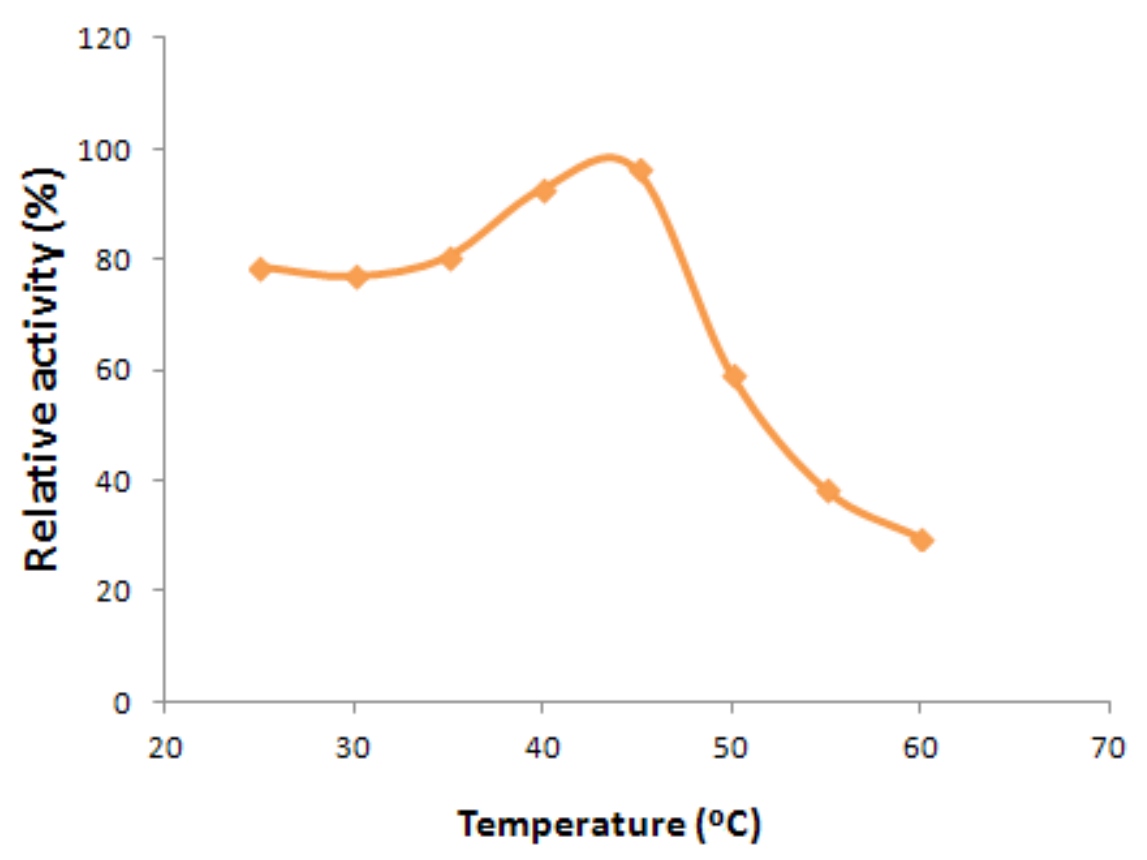

Figure (4): Effect of different temperatureson Laccase stability.

Most cold-adapted enzymes exhibit poor thermal stability at temperatures above $40^{\circ} \mathrm{C}$, and their activity decreases as temperature increases. ${ }^{[24]}$

The reduction of activity above $40^{\circ} \mathrm{C}$ is due to sensitivity to high temperature, reflecting the effect of temperature on the three dimensional structure of protein by damaging R-groups of amino acids which lead to denaturation of protein and losing its activity. In general, laccases are stable at $30-50^{\circ} \mathrm{C}$ and rapidly lose activity at temperatures above $60^{\circ} \mathrm{C}^{[25]}$.

Determination Km, Vmax Values: As shown in Figure (5) relation between substrate concentration ABTS and enzyme activity. Activity was measured at different ABTS concentrations (0.1, 0.15, 0.2, 0.25 and $0.3 \mathrm{mM}$ ) in $0.1 \mathrm{mM}$ of sodium acetate buffer at $\mathrm{pH} 5$. 


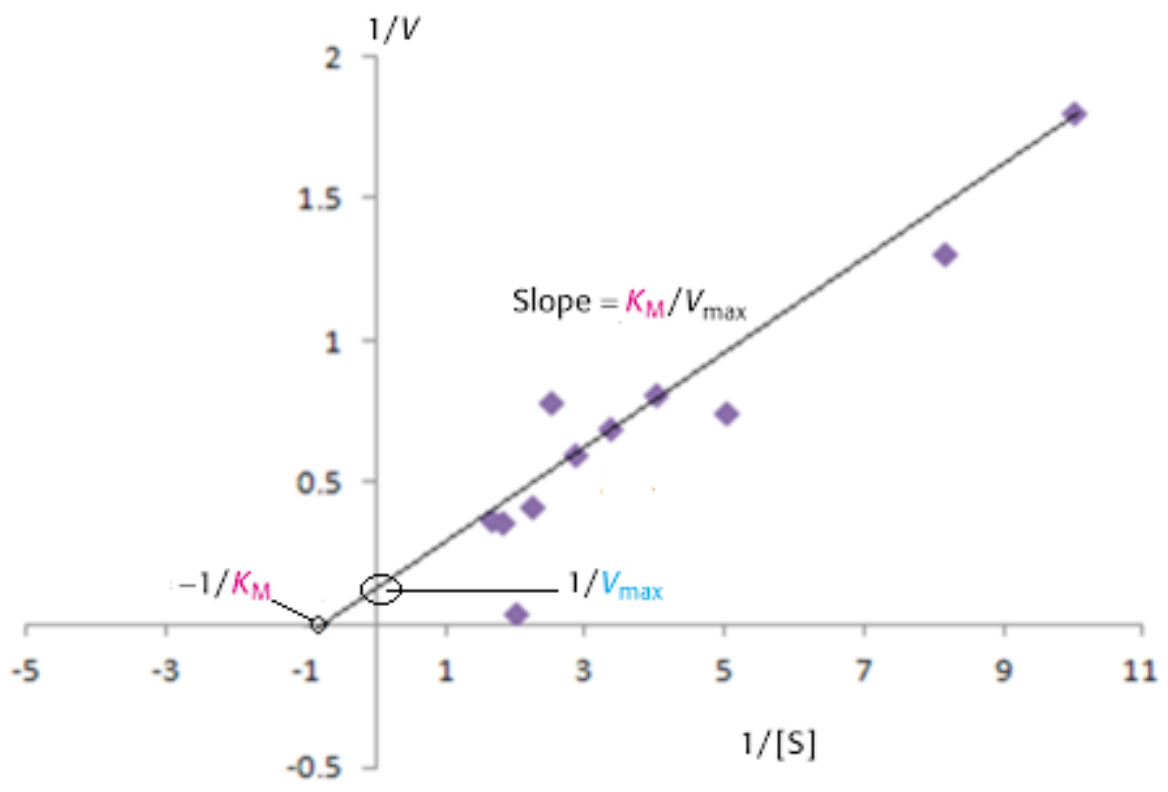

Figure (5): Lineweaver-Burk double reciprocal plot of (1/Vo) versus the [So] for the purified laccase.

Singhal et $a .^{[34]}$ characterized laccase enzyme activity produced by Cryptococcus albidus, ABTS was used as a substrate. By Michaelis-Menten kinetics the $\mathrm{K}_{\mathrm{m}}$ was $0.8158 \mathrm{mM}$ and $\mathrm{V}_{\max }$ was $1527.74 \mathrm{U} / \mathrm{mg}$. The Km of laccase purified Bacillus subtilis CotA by Martins et $a{ }^{[7]}$ was $0.106 \mathrm{mM}$. Laccase purified from $K$. pneumoniae by using ABTS as substrate. The $\mathrm{K}_{\mathrm{m}}$ values were $0.467,3.97$ and $0.38 \mathrm{mM}$ for NITW715076, NITW715076_1 and NITW715076_2 K. pneumoniae strains, respectively ${ }^{[26]}$.

\section{Conclusion}

K. pneumonia have been proved to its ability to produce laccase. And The molecular weight of laccase was determined at $120 \mathrm{KD}$. The optimum $\mathrm{pH}$ of enzyme activity and stability is 4.5 and 6.5 , receptivity. The optimum temperature for laccase activity is $40^{\circ} \mathrm{C}$ while forstability is $\left(20-35^{\circ} \mathrm{C}\right)$.

Conflict of Interest: The author knows of no financial interest or any conflict of interest relative to this article.

\section{Funding: Self}

Ethical Clearance: Not required

\section{References}

1. Ghodake, GS, Yang, J, Shinde, SS, Mistry, BM, Kim, DY and Sung, JS, et al. Paper waste extracted $\alpha$-cellulose fibers super-magnetized and chitosan functionalized for covalent laccase immobilization. Bioresource Technology, 2018; 261:420-427.

2. Guan, ZB, Shui, Y, Song, CM., Zhang, N, Cai, YJ. and Liao, XR. Efficient secretory production of CotA-laccase and its application in the decolorization and detoxification of industrial textile wastewater. Environmental Science and Pollution Research, 2015; 22:9515-9523.

3. Guan, ZB, Liao, Q, Wang, HR, Chen, Y and Liao, XR. Bacterial laccases: promising biological green tools for industrial applications. Cellular and Molecular Life Sciences;2018; 75:3569-92.

4. Brisse, S, Issenhuth-Jeanjean, $\mathrm{S}$ and Grimont, P. Molecular serotyping of Klebsiella species isolates by restriction of the amolified capsular antigen gene cluster. Journal of Clinical Microbiology, 2004; 42: 3388-3398.

5. Sharma, P, Goel, R and Capalsh, N. Bacterial laccase, World Journal of Microbiology and Biotechnology, 2007; 23: 823-832

6. Clive, D. A guide to protein Isolation. Kluer Academic Publisher. New York, USA 2002, 1-186.

7. Martins, LO. Soares, CM; Pereira, MM, Teixeira MT, Costa, GH and Henriques, AO. Molecular and biochemical characterization of a highly stable bacterial laccase that occurs as a structural component of the Bacillus subtilis endospore coat. 
Journal of Biological Chemistry,2002; 277: 1884918859.

8. Suzuki, T, Endo, K, Ito, M,Tsujibo,H, Miyamoto,K. and Inamori, YA, Thermostable laccase from Streptomyces lavendulae REN-7: purification, charac- terization, nucleotide sequence and expression . Bioscience, Biotechnology, and Biochemistry, 2003; 67:2167-2175.

9. Shi, X, Liu, Q, Ma, J, Liao, H, Xiong, X, Zheng, K, Wang, T, Liu, X, Xu, T, Yuan, S, Zhang, X and Zhu, Y. An acid-stable bacterial laccase identified from the endophyte Pantoeaananatis Sd-1 genome exhibiting lignin degradation and dye decolorization abilities, Biotechnol Lett,2015; 37:2279-2288.

10. Liu, L, Lin, Z, Zheng, T, Lin, L, Zheng, C. and Lin, $Z$. Fermentation optimization and characterization of the laccase from Pleurotusostreatus strain 10969. Enzyme and Microbial Technology,2009; 44: 426433.

11. Bradford, MM. A rapid and sensitive method for the quantitation of microorganism's protein utilizing the principle of protein-dye binding. Analytical Bioch, 1976, 72: 248-254.

12. Segel, IH. Biochemical calculations,JohnWiely and sons.NewYork.2nd edition.1976; pp34.

13. Singh,G. Ahuja, N, Batish, M,Capalash, N. and Sharma, P. Biobleaching of wheat strawrich-soda pulp with alkalophilic laccase from $\gamma$-proteobacterium JB: Optimization of process parameters using Response Surface Methodology. BioResources Technology, 2008; 99, 7472-7479.

14. Siroosi, M, Amoozegar, MA and Khajeh, K. Purification and characterization of an alkaline chloride-tolerant laccase from a halotolerant bacterium, Bacillus sp. strain WT. Journal of Molecular Catalysis B: Enzymatic, 2016; 134:8997.

15. Verma, A and Shirkot, P. Purification and characterization of thermostable laccase from thermophilic Geobacillusthermocatenulatus MS5 and its applications in removal of textile dyes Sch Acad.Journal of Biosciences, 2014; 2:479-485.

16. Liu, Q, Luo, L, Wang, $X$, Shen, $Z$ and Zheng, L. Comprehensive analysis of rice laccase gene (OsLAC) family and ectopic expression of OsLAC10 enhances tolerance to copper stress in Arabidopsis. International Journal of Molecular Sciences, 2017; 18:209.
17. Litwińska, K, Bischof, F, Matthes, F, Bode, R,Rutten, $\mathrm{T}$ and Kunze G. Characterization of recombinant laccase from Trametes versicolor synthesized by Arxulaadeninivorans and its application in the degradation of pharmaceuticals. AMB Express, 2019; 9:102.

18. $\mathrm{Xu}, \mathrm{F}$. Effects of redox potential and hydroxide inhibition on the $\mathrm{pH}$ activity profile of fungal laccases. Journal of Biological Chemistry, 1997; 272: 924-928.

19. Abdulah AR. The use of partially purified laccase produced by some fungal isolates in Aflatoxin B1 degradation. M.Sc. Thesis in Biotechnology, University of Baghdad College of Science Department of Biotechnology.2008.

20. Siroosi, M, Amoozegar, MA and Khajeh, K. Purification and characterization of an alkaline chloride-tolerant laccase from a halotolerant bacterium, Bacillus sp. strain WT. Journal of Molecular Catalysis B: Enzymatic, 2016; 134:8997.

21. Demissie, AG and Kumar, A Isolation of novel bacteria isolate from soil for production of extra-cellular laccase enzyme. International Journal of Emerging Technology and Advanced Engineering,2014; 4:404-407.

22. Dhiman, K and Shirkot, P. Bioprospecting and molecular characterization of laccase producing bacteria from paper mills of Himachal Pradesh. Proceedings of the National Academy of Sciences, India, Section B,2015; 85:1095-1103.

23. Ke, MM, Ramesh, B, Hang, YA and Liu, ZD. Engineering and characterization of a novel low temperature active and thermo stable esterase from marine. Enterobacter cloacae. International Journal of Biological Macromolecules, 2018; 118, 304-310.

24. Xu, F. Effects of redox potential and hydroxide inhibition on the $\mathrm{pH}$ activity profile of fungal laccases. Journal of Biological Chemistry. 1997; 272: 924-928.

25. Singhal, A, Choudhary, G and Thakur, I. Characterization of laccase activity produced by Cryptococcus albidus. Preparative Biochemistry and Biotechnology,2012; 42(2).

26. Gaur, N, Narasimhulu, K and Setty, YP. Extraction of ligninolytic enzymes from novel Klebsiella pneumoniae strains and its application in wastewater treatment. Applied Water Science,2018; Vol.8. 